9. Левиикая Н.Г., Шаталова О.В. Современные тенденции изменения климата и их влияние на продуктивность сельскохозяйственных культур в Нижнем Поволжье // Проблемы и пути преодоления засухи в Поволжье. Саратов, 2000. Ч.2. С.33-47.

10. Рыхлов А.Б., Левицкая Н.Г. Изменения климата и их агроклиматические последствия в Нижнем Поволжье // Современные глобальные и региональные изменения геосистем: Материалы Всерос. науч. конф., посвящ. 200-летию Казанского ун-та. Казань, 19-21 окт. 2004 г. Казань, 2004. C.370-371.

УДК $551.582(470.44)$

\section{МОНИТОРИНГ КЛИМАТА САРАТОВСКОЙ ОБЛАСТИ}

\author{
С.И. Пряхина, Ю.Н. Фридман, М.Ю. Васильева
}

Саратовский государственный университет, кафедра метеорологии и климатологии

E-mail: kafmeteo@sgu.ru

В работе дается обоснование агроклиматических ресурсов, а также описание таких уникальных климатических явлений, как зональность и сезонность. В основу характеристики климата Саратовской области положены наблюдения метеорологических элементов за 50-70-летний период, а средние характеристики температуры рассчитаны более чем за 100 лет.

\section{Monitoring of Climate in Saratov Kegion}

\section{S.I. Pryakhina, Yu.N. Fridman, M.Yu. Vasilieva}

In the present article the authors give substantiation of agroclimatic resources and description of such unique climatic phenomena as zoning and seasonality. Monitoring of meteorological elements for the period of 50-70 years forms the essence of characteristics of Saratov region climate, average temperature characteristics have been calculated for the period of more than 100 years.

Проблема изменения глобального климата под влиянием естественных факторов и хозяйственной деятельности человека является одной из актуальнейших на сегодняшний день, в том числе и для Саратовской области.

Потепление климата, которое наблюдается в последние 50 лет, влияет на подбор зерновых культур, их урожайность, технологию возделывания и структуру посевных площадей.

В основу характеристики климата Саратовской области положены наблюдения метеорологических элементов за 50-70-летний период, а средние характеристики температуры рассчитаны более чем за 100 лет (с 1881 по 2000 г.).
11. Скляров Ю.А., Иванова Г.Ф. Проблема глобального и регионального изменения климата // Изв. Сарат. ун-та. Новая сер. 2002. Т.2, вып.2. С.44-48.

12. Скляров Ю.А., Иванова Г.Ф. Некоторые аспекты изменения климата и прогнозные оценки для города Саратова / Сарат. гос. ун-т. Саратов, 2003. 20 с. Деп. в ВИНИТИ 30.09.03 г. № 1749-В 2003.

13. Суркова Г.В., Пона К. Колебания изменчивости температуры воздуха и атмосферных осадков как агрометеорологический фактор // Метеорология и гидрология. 2000. №6. C.85-99.

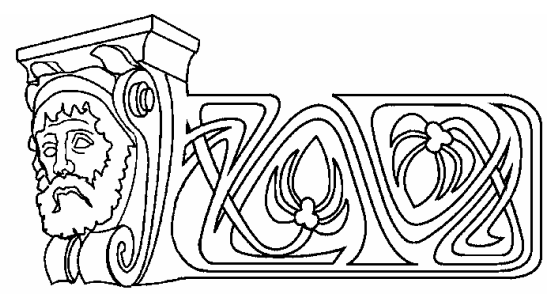

Анализ многолетнего статистического материала позволил авторам отразить динамику изменения климата области по сезонам и степень его влияния на сельскохозяйственное производство.

На территории области создаются благоприятные условия для проявления климатических закономерностей - меридиональной и широтной. Первая закономерность характеризуется общим нарастанием континентальности климата в восточном направлении. Вторая - выражена в широтной биоклиматической зональности, обусловленной возрастанием с севера на юг притока тепла к земной поверхности при одновременном уменьшении в том же направлении увлажнения. Четко выраженная смена широтных зон является уникальной особенностью климата области. В направлении с севера на юг ее пересекают четыре крупные природные зоны: лесостепь, засушливая черноземная степь, сухая степь с темно-каштановыми и бурыми почвами и полупустыня. Такое разнообразие природных зон говорит о больших возможностях сельскохозяйственного производства.

Своеобразие климата Саратовской области состоит в его засушливости, высокой степени континентальности и большой изменчивости погоды от года к году. Для него характерна холодная малоснежная зима, короткая засушливая весна и сухое лето. 
Климат правобережья, в особенности северо-западных районов, менее континентален по отношению к районам левобережья. Годовая амплитуда средних температур наиболее холодного (январь) и наиболее теплого (июль) месяцев в Балашове равна $31,2^{\circ} \mathrm{C}$, в Саратове $-32,4^{\circ} \mathrm{C}$, в Ершове $-35,1^{\circ} \mathrm{C}$, в Александровом Гае $-36,3^{\circ} \mathrm{C}$. С севера и северо-запада плавное нарастание континентальности идет до Ершова и Александрова Гая, а далее к югу континентальность падает за счет смягчающего действия водной поверхности Каспия [1].

Наиболее теплым месяцем является июль. Среднемесячная температура в июле изменяется по области от $20^{\circ} \mathrm{C}$ на северозападе до $24^{\circ} \mathrm{C}$ на юго-востоке. Наиболее холодный месяц - январь. Хотя температура января по территории изменяется незначительно от $-11^{\circ} \mathrm{C}$ до $-13^{\circ} \mathrm{C}$, но в отдельные холодные годы она может опускаться до $-44^{\circ} \mathrm{C}$, а летом в жаркие дни доходит до $42^{\circ} \mathrm{C}$.

Область располагает большими тепловыми ресурсами. Сумма активных температур воздуха выше $10^{\circ} \mathrm{C}$ изменяется от $2400^{\circ} \mathrm{C}$ на севере и северо-западе до $3100^{\circ} \mathrm{C}$ на юговостоке, что позволяет возделывать множество сельскохозяйственных культур.

Период вегетации в Саратове характеризуется как длинный (151-180 дней) и очень длинный (более 180 дней). В северных регионах области активная вегетация составляет 121-150 дней и характеризуется средней продолжительностью. В центральных и южных регионах период вегетации составляет более 150 дней (в девяностые годы - более 180 дней) и характеризуется как длинный и очень длинный [2].

В большей части области с продолжительностью активной вегетации 150-180 дней создаются благоприятные условия для возделывания сельскохозяйственных культур со сравнительно повышенными требованиями к теплу.

Согласно агроклиматическому районированию страны по Д.И.Шашко, Саратовская область относится к умеренному тепловому поясу культур средней спелости с суммой температур выше $10^{\circ} \mathrm{C}$ в пределах 2200$2800^{\circ} \mathrm{C}$ (средние и поздние сорта зерновых, зернобобовых, кукурузы на зерно, подсолнечника на семена, рис, соя, сахарная свекла, бахчевые и др.) и среднепоздней спелости с требованиями к суммам активных температур за период вегетации $2800-3400^{\circ} \mathrm{C}$ (экологические типы культур те же, но более поздних сортов).

Самые поздние заморозки весной бывают в первой декаде июня, самые ранние заморозки осенью в правобережье - во второй, в левобережье - в третьей декаде сентября.

Значительная часть термических ресурсов остается неиспользованной из-за недостатка влаги.

Среднегодовое количество осадков меняется по районам области от 310 до 500 мм, причем в период вегетации основных зерновых культур выпадает 25-30\% этого количества. Поэтому важнейшими задачами земледелия здесь являются введение засухоустойчивых культур и сортов, разработка и освоение влагосберегающих технологий их возделывания.

Главная особенность климата - частая повторяемость засух и суховеев. За последние 100 лет повторяемость засух в период весенне-летней вегетации составила в среднем $46 \%$, то есть практически каждый второй год отмечаются засушливые явления той или иной интенсивности.

В умеренных широтах изменения составляющих теплового и водного режима, а следовательно, и погодных условий достаточно велики, поэтому смена времен года один из самых важных природных ритмов. В области времена года выражены ярко. Главные сезоны - летний и зимний - длятся по 4,5 месяца, а переходные - по 1,5 месяца. В динамике основных сезонов наблюдается трехфазная, а переходных - двухфазная структура.

В конце октября на территории области радиационный баланс становится отрицательным. Начинают преобладать процессы выхолаживания подстилающей поверхности, которые приводят к переходу средней суточной температуры через $0^{\circ} \mathrm{C}$ и установлению в начале ноября зимнего сезона.

В структуре зимнего сезона выделяются три фазы - «предзимье», «разгар зимы», «спад зимы».

Зима в области холодная и продолжительная. Среднемесячная температура января и февраля на всех станциях ниже $-10^{\circ} \mathrm{C}$. 
Зимой в области часто наблюдаются оттепели. В среднем они составляют 10-11 дней за январь и февраль, но бывают годы, когда число дней с оттепелью (декабрьфевраль) возрастает до 30 и более. Оттепели среди зимы следует рассматривать как неблагоприятное метеорологическое явление, так как они приводят к уплотнению снега и образованию притертой ледяной корки, которая повреждает зимующие растения. Фенологические наблюдения за длительный период времени по Саратову и его окрестностям дают следующую картину продолжительности сезонов.

Зима в Саратове - 126 дней (15.11 20.03) - с начала замерзания прудов и до первых проталин на открытых равнинах.

Весна - это период времени от разрушения устойчивого снежного покрова и перехода средней суточной температуры через $0^{\circ} \mathrm{C}$ к положительным значениям до окончания заморозков в воздухе и перехода средней суточной температуры через $10^{\circ} \mathrm{C}$. Весна в регионе очень активная, и продолжается в среднем 40-45 дней. В структуре весны выделяется две фазы: «снеготаяния» и «разгара весны» [2].

Большой интерес для сельского хозяйства представляет продолжительность периода между датами перехода температуры через $0^{\circ}$ и $10^{\circ} \mathrm{C}$, т.е. до наступления активной вегетации растений. За этот период поспевает почва, производятся сельскохозяйственные работы, связанные с ее обработкой и проведением сева. Средняя многолетняя дата перехода температуры через $0^{\circ} \mathrm{C}$ в области наблюдается 27 марта, а через $10^{\circ} \mathrm{C}-20$ апреля. Продолжительность периода от $0^{\circ}$ до $10^{\circ} \mathrm{C}$ составляет 25 дней. В среднем с начала и до третьей декады апреля идет фаза «ранней весны». С 11 по 16 апреля температура устойчиво переходит через $5^{\circ} \mathrm{C}$ и возобновляется вегетация озимых культур. В последнюю неделю апреля средняя суточная температура воздуха уже превышает $10^{\circ} \mathrm{C}$ и фенологи считают, что начинается «разгар весны». Это время от развертывания первых листьев у березы до окончания цветения яблонь, время дружного цветения большинства садовых и ягодных культур.
Лето в области засушливое и продолжительное. В его динамике выделяется три фазы: «предлетье», «разгар лета» и «спад лета».

Первый период начинается в мае и заканчивается в первой декаде июня. Второй период продолжается до 25 августа, до перехода средней суточной температуры через $15^{\circ} \mathrm{C}$. Третий период длится до третьей декады сентября.

По наблюдениям фенологов лето в Саратове продолжается 115 дней с момента отцветания яблонь и до первых слабых заморозков на почве (24.05 - 15.09).

Осенний сезон на территории области короткий - 45 дней. Осенью происходит смена летнего типа циркуляционных процессов на зимний. Смена в циркуляции приводит к прекращению засушливых погод. В осеннем сезоне наблюдается две фазы. Первая - «становление осени», а вторая - «поздняя осень». К началу первой фазы деревья и кустарники имеют осеннюю окраску, поэтому ее называют еще «золотой осенью».

В первую фазу осени характерны возвраты тепла - «бабье лето». В такие дни стоит малооблачная, сухая погода. Средняя суточная температура даже в октябре поднимается до $20^{\circ} \mathrm{C}$.

Период перехода средней суточной температуры воздуха от $10^{\circ}$ до $5^{\circ} \mathrm{C}$ составляет 20-25 дней. В этот период производятся работы, связанные с осенней обработкой почвы и уборкой урожая. По многолетним наблюдениям, в области осенью стоит сухая погода с большим количеством солнечных дней. Озимые культуры набирают $300^{\circ} \mathrm{C}$ активных температур и благополучно проходят фазы закаливания.

В последние шесть десятилетий в области проявляют себя черты глобального потепления климата. Анализ ежедневных метеорологических данных по ст. Саратов за 19412000 гг. за зимний период (с ноября по март) показал, что средняя многолетняя сумма отрицательных температур составила $-1041,1^{\circ} \mathrm{C}$. Самый холодный зимний период наблюдался в 1941-1942 гг., когда сумма отрицательных температур составила $-1651,2^{\circ} \mathrm{C}$, самый теплый был в 1989-1990 гг. В этот зимний сезон сумма отрицательных температур составила всего $-362,4^{\circ} \mathrm{C}$. 
Анализ динамики климатических сумм температур, накопленных за зимний сезон последних шести десятилетий, показал, что второе десятилетие (1951-1960 гг.) было самым холодным, в последующие десятилетия, хотя и отмечались отдельные холодные зимы, но наблюдалась устойчивая тенденция потепления зим. Средняя сумма температур за зимний период по десятилетиям: 19411950, 1951-1960, 1961-1970, 1971-1980, 19811990, 1991-2000 гг. составила соответственно $-1174,-1214,-1040,-932,-875,-907^{\circ} \mathrm{C}$.

Существенные изменения климата области в сторону потепления особенно заметны в холодную часть года. С 1980-х гг. начинают преобладать положительные аномалии температуры во все зимние месяцы, в отдельных случаях аномалия температуры достигала весьма значительных величин более $8^{\circ} \mathrm{C}$.

Столь резкое потепление климата на юге Русской равнины не является случайным, а представляет собой часть глобального потепления, особенно усилившегося в 1980-х годах.
Тщательный анализ ежедневного метеорологического материала по станциям Саратовской области показал, что потепление и увеличение осадков в зимний период создают более благоприятные условия для зимующих культур, а повышение температуры воздуха в мае в последние десятилетия способствует усилению засушливых явлений в начале лета, что неблагоприятно сказывается на возделывании яровых зерновых культур. Увеличение посевных площадей под озимые культуры будет способствовать более рациональному использованию естественных природных ресурсов региона.

\section{Библиографический список}

1. Пряхина С.И., Скляров Ю.А., Заварзин А.И. Природные ресурсы Нижнего Поволжья и степень их использования зерновыми культурами. Саратов, 2001. 66 с.

2. Пряхина С.И. Климатическая характеристика сезонов. Климат Саратова. Л., 1987. С.91-102. 